\title{
Dietary Brown Propolis Extract Modulated Nonspecific Immune System and Intestinal Morphology of Pacu Piaractus mesopotamicus
}

Angelita Muzzolon ${ }^{1}$

https://orcid.org/0000-0003-1218-5439

Álvaro José de Almeida Bicudo²
https://orcid.org/0000-0003-4524-3973

Tatiane Luiza Cadorin Oldoni ${ }^{3}$

https://orcid.org/0000-0002-5187-6032

\section{Ricardo Yuji Sado ${ }^{*}$}

https://orcid.org/0000-0002-6987-9290

${ }^{1}$ Technological Federal University of Paraná, Dois Vizinhos, Parana, Brazil; 2Federal University of Parana, Palotina, Parana, Brazil; ${ }^{3}$ Technological Federal University of Paraná, Department of Chemistry, Pato Branco, Parana, Brazil.

Editor-in-Chief: Alexandre Rasi Aoki

Associate Editor: Marcelo Ricardo Vicari

Received: 2020.12.16; Accepted: 2021.05.02.

${ }^{*}$ Correspondence: ricardoysado@utfpr.edu.br; Tel: +55-46-35368416 (R.Y.S).

\section{HIGHLIGHTS}

- Brown propolis from Southwest of Parana modulated pacu immune system.

- Dietary supplementation of propolis extract increased fish serum lysozyme concentration.

- Dietary supplementation of propolis extract increased fish circulating organic defense cells.

- Brown propolis extract did not cause toxic effects on pacu.

Abstract: The immunomodulatory and growth promoter effects of brown propolis ethanolic extract (PEE) were determined in pacu. Fish $(28.4 \pm 0.4 \mathrm{~g})$ were randomly distributed into 12 polyethylene circular tanks (250 L, 30 fish per tank) and fed for 60 days with a commercial diet (32\% crude protein) supplemented with $0.0,1.5,3.0$ and $4.5 \%(\mathrm{v} / \mathrm{w})$ of PEE in a totally randomized experimental design $(n=3)$. Fish organic defense cells numbers such as thrombocytes and neutrophils increased $(p<0.05)$ in fish fed $3.0 \%$ dietary PEE. Serum lysozyme concentration also increased $(p<0.05)$ in fish fed 1.5 and $3.0 \%$ PEE supplementation when compared to unsupplemented fish. Growth parameters were not influenced $(p>0.05)$ by treatments. Moreover, dietary PEE decreased $(p<0.05)$ fish intestinal muscular thickness when compared to control treatment. Intestine villi height also significantly decreased in fish fed 3.0\% PEE. Long term dietary PEE at $3.0 \%$ supplementation level modulated fish nonspecific immune system and it is a non-toxic substance for pacu.

Keywords: fish hematology; fish immunology; nutrition; pacu; phytoterapic. 


\section{INTRODUCTION}

World aquaculture production has increased in the past 30 years [1] as well as for neotropical fish species in Latin America, based on characiforms such as pacu Piaractus mesopotamicus, tambaqui Colossoma macropomum and their hybrids [2].

Fish are submitted to several unavoidable stressors (overcrowding and poor water quality) in intensive production systems which impairs fish health and consequently, growth, immune system and disease resistance [3,4]. In addition, the indiscriminate use of antibiotics to control fish disease outbreaks resulted in selection of several resistant pathogenic microorganisms [5,6] and undermine the profitability and sustainability of aquaculture [7]. Thus, the use of natural compounds to modulate the immune system and growth of aquatic organism is a promising method with low-environmental impact for disease control $[4,8]$ since it does not result neither bacterial resistance nor residues in fish flesh [9].

Propolis, also known as "bee glue", is manufactured product by bees Apis mellifera, made from plant exudates and used to building and reparation of hive, as well as protection against microorganisms, with more than 200 bioactive compounds $[10,11]$. As regards its role on the immune system, propolis has many different biological and pharmacological properties such as antibacterial, antifungal, antiviral, antiprotozoal, antioxidant, anti-inflammatory and immunostimulant activities [11-17]. Due to these characteristics, propolis can be used as additive in aquafeeds to improve fish health and growth.

Promising results on the use of propolis and its extracts (aqueous and ethanolic) to improve growth, immune system, stress and disease resistance was observed in several fish species such as Nile tilapia Oreochromis niloticus [18], Mozambique tilapia Oreochromis mossambicus [19], rainbow trout Onchorhynchus mykiss [20-22], common carp Cyprinus carpio [23] and Japanese eel Anguilla japonica [24]. However, it is possible that dose response to dietary propolis supplementation in aquafeeds may be species dependent [25].

Pacu P. mesopotamicus, an omnivorous Characin native from Parana, Paraguay and Uruguay river basins, is widely produced in Latin American fish farming industry [26]. To our knowledge, there are no previous scientific paper published regarding the effects of dietary propolis supplementation for pacu. Thus, the study evaluated the effects of increasing levels of dietary brown propolis ethanolic extract (PEE) on health and growth of pacu juveniles.

\section{MATERIALS AND METHODS}

\section{Fish rearing conditions}

Trial was set up in indoor (12hr light:12hr dark photoperiod) water recirculation system composed of 12 polyethylene circular tanks (250-L) and biological filtration with continuous aeration and temperature control. The pacu juveniles $(28.4 \pm 0.4 \mathrm{~g})$ were obtained from a commercial fish farm (Piscicultura Daniela, Francisco Beltrao, Parana, Brazil). At laboratory facilities, fish were previously acclimated to experimental conditions and basal diet for 15 days. Water quality parameters were monitored electronically in a daily basis with portable oximeter (HI 98193, HANNA ${ }^{\circledR}$ Brasil, Barueri, SP) and digital pH meter (MPA 210, MS TECNOPON ${ }^{\circledR}$, Piracicaba, SP): temperature $\left(26.4 \pm 1.3^{\circ} \mathrm{C}\right)$, dissolved oxygen $(5.2 \pm 0.4 \mathrm{mg} / \mathrm{L})$ and $\mathrm{pH}(6.9 \pm 0.2)$. Before experimental procedures, this research was approved by the Ethics Committee on Animal Use (CEUA) of UTFPR (protocol no 2013-007).

\section{Experimental procedures}

A commercial extruded $(2.0 \mathrm{~mm}$ pellets) fish feed formulation (32\% crude protein, $5 \%$ crude fat, $10 \%$ crude fiber, $12 \%$ ash, Anhambi Alimentos Ltda., Itapejara do Oeste, Parana, Brazil) was used as basal diet. The basal diet was stored in freezer $\left(-20^{\circ} \mathrm{C}\right)$. Every seven days, the amount of feed sufficient for that period was separated and it was sprayed $0.0 ; 1.5 ; 3.0$ and $4.5 \%$ volume/weight of propolis ethanolic extract (PEE) and stored in dark bottles under refrigeration $\left(4^{\circ} \mathrm{C}\right)$ until use to avoid propolis biocompounds oxidation. The extraction of PEE from brown propolis, and the determination of antioxidant activity, total phenolics and flavonoids content was done according to Oldoni and coauthors [10] (Table 1). The brown propolis was collected from selected colonies of Africanized honey bees (A. mellifera) at experimental apiary at Federal Technological University of Parana (Southwest of Parana - latitude: $-25.699063^{\circ}$, longitude: $-53.095273^{0}$, altitude: $546 \mathrm{~m})$. 
Table 1. Antioxidant activity and bioactive compounds content of propolis ethanolic extract (PEE) from brown propolis.

\begin{tabular}{ccccc}
\hline \multicolumn{2}{c}{$\begin{array}{c}\text { Antioxidant activity } \\
\text { ABTS }\end{array} \begin{array}{c}\text { DPPH } \\
\mu \mathrm{mol} \text { of Trolox/g }\end{array}$} & $\begin{array}{c}\text { FRAP } \\
\mu \mathrm{mol} \text { of Fe } \mathrm{Fe}^{2+} / \mathrm{g}\end{array}$ & $\begin{array}{c}c \\
\text { Phenolics } \\
\text { mg GAE} / \mathbf{g}\end{array}$ & $\begin{array}{c}\text { Flavonoids } \\
\text { mg Quercetin } / \mathbf{g}\end{array}$ \\
\hline $95.2 \pm 4.4$ & $40.0 \pm 1.9$ & $259.3 \pm 9.5$ & $15.5 \pm 0.5$ & $0.81 \pm 0.04$
\end{tabular}

ABTS: 2-2'-azino-di-(3-ethylbenzthiazoline sulfonic acid) method

DPPH: 2,2-diphenyl-1-picrylhydrazyl hydrate free scavenging method

FRAP: Ferric reducing antioxidant power method

Fish were randomly distributed into 12 polyethylene circular tanks (250-L, 30 fish per tank), each tank representing a replication $(n=3)$. Fish were hand-fed daily with experimental diets for 60 days until apparent satiation (09hr:00min and 17hr:00min).

\section{Sampling}

At the end of feeding trial, fish were fasted for $24 \mathrm{hr}$, sedate with alcoholic solution of benzocaine (50 $\mathrm{mg} / \mathrm{L}$ ) and sampled for hematological, immunological and biometrical data. To determine intestine histology, after blood sampling, fish were sacrificed by anesthetic overdose (100 mg/L alcoholic benzocaine solution) and later medullary section.

\section{Hematological and immunological analysis}

Blood samples for hematological and immunological analyses of four fish per tank (12 fish per treatment) were drawn from caudal vein using sterilized needles and syringes previously rinsed with heparin. Total red blood cell count (RBC) was performed in Neubauer chamber using formaldehyde citrate buffer as diluent, the hematocrit was determined in microhematocrit tubes after centrifugation for 5 minutes at $10,000 \mathrm{~g}$ and hemoglobin content was determined by the cyanmethemoglobin method. Hematimetric indexes was calculated according to Wintrobe [27].

Blood smears from sampled fish were stained with May-Grünwald-Giemsa stain [28] to perform differential and total leukocytes count and thrombocytes count by the indirect method [29]. Total plasma protein concentrations were determined using a portable refractometer (RHC-200/ATC, 0.0 12.0 g/dL) after total blood centrifugation and plasma collection [30].

Leukocyte production of reactive oxygen species (respiratory burst) was determined by nitroblue tetrazolium (NBT) colorimetric assay [31]. An aliquot of $100 \mu \mathrm{L}$ of total blood was mixed with $100 \mu \mathrm{L}$ of $0.2 \%$ NBT solution (Nitrotetrazolium Blue Chloride, Sigma-Aldrich®, St Louis, MO, USA) and incubated for 30 min at $25^{\circ} \mathrm{C}$. After the incubation period, $50 \mu \mathrm{L}$ of this suspension was added to $1.0 \mathrm{~mL}$ of DMF (N, Ndimethylformamide, Sigma-Aldrich $\AA$, St Louis, MO, USA) and centrifuged (755 g) for 5 min. Finally, the absorbance of the supernatant was measured at $540 \mathrm{~nm}$ wavelength using a spectrophotometer.

Serum lysozyme concentration was determined based on the lysis of Micrococcus lysodeikticus (SigmaAldrich, St Louis, MO, USA) as standard [32]. Fish serum samples were heated ( $56^{\circ} \mathrm{C}$ for $30 \mathrm{~min}$ ) to inactivate complement system proteins and certify that lysis of $M$. lysodeikticus had occurred only by lysozyme action. Then, $150 \mu \mathrm{L}$ of fish serum and $150 \mu \mathrm{L}$ sodium phosphate buffer was added to a glass cuvette and incubated at $26^{\circ} \mathrm{C}$ for $2 \mathrm{~min}$ in spectrophotometer and $300 \mu \mathrm{L}$ of $M$. lysodeikticus suspension $(0.2 \mathrm{mg} / \mathrm{mL}$ sodium phosphate buffer) was added to complete a $600 \mu \mathrm{L}$ final volume. The difference between the initial and final optical density ( $\triangle$ OD) was measured between 0.5 and $5 \mathrm{~min}$ at $450 \mathrm{~nm}$ wavelength using a spectrophotometer. The equation of the lysozyme calibration curve was used to determine the serum lysozyme levels.

\section{Growth performance}

Growth performance was calculated as follows: weight gain (WG $(\mathrm{g})=$ final weight - initial weight); specific growth rate (SGR (\% body weight/day) $=100 \times[($ In final weight - In initial weight) $\div$ days of experiment]) and feed conversion ratio (FCR $(\mathrm{g} / \mathrm{g})=$ total feed intake $\div$ weight gain).

\section{Intestinal morphology}

A sample of the proximal intestine of three fish per tank (nine fish per treatment) was sampled and fixed for 24h in Alfac solution. The intestine histology was performed according to Sado and coauthors [33]. Intestine sections $(5 \mu \mathrm{m})$ were stained in hematoxylin and eosin (H \& E) and documented using digital camera 
(AxioCam ERc5s, Carl Zeiss, Germany) connected to a light microscope (Primo Star, Carl Zeiss, Germany). The images were analyzed by using specific software (ZEN, ZEN Blue Edition, Carl Zeis, Germany) for intestinal villi height and muscular layer thickness measures.

\section{Statistical analysis}

Significant effects of dietary PEE after 60 days trial was analyzed by one-way analysis of variance (ANOVA) at $5 \%$ probability. A polynomial regression analysis was performed for growth parameters. Means of statistically difference were compared by Tukey's test $(\alpha=0.05)$ after results tested for normality (Cramer Von Mises) and homoscedasticity (Brown-Forsythe).

\section{RESULTS}

\section{Hematology and immunology}

There was no effect ( $p>0.05$ ) of dietary supplementation of PPE on some hematological parameters of juvenile pacu (Table 2). Although the absent of significant effect on total leukocytes numbers, 3.0\% dietary PEE increased $(p<0.05)$ the number of fish neutrophils when compared to control (unsupplemented) diet. In the same way, thrombocyte number also was significantly higher in fish fed 3.0\% PEE diet than control.

Dietary PEE supplementation also affected fish immune system. Serum lysozyme concentration was significantly higher in fish fed 1.5 and 3.0\% PEE supplementation when compared to control group (Figure 1). However, no effect ( $p>0.05)$ was observed on leukocyte respiratory burst (Table 2$)$.

Table 2. Hematological and immunological parameters (mean $\pm \mathrm{SD}$ ) of juvenile pacu Piaractus mesopotamicus fed increasing levels of propolis ethanolic extract in diet for 60 days.

\begin{tabular}{|c|c|c|c|c|c|}
\hline \multirow{2}{*}{ 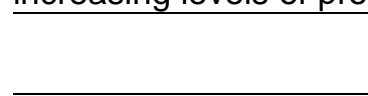 } & \multicolumn{4}{|c|}{ Propolis ethanolic extract levels (\% of diet) } & \multirow{2}{*}{$\begin{array}{c}\text { One-way ANOVA } \\
\text { ( } p \text {-values })\end{array}$} \\
\hline & 0.0 & 1.5 & 3.0 & 4.5 & \\
\hline $\mathrm{Htc}(\%)$ & $34.1 \pm 1.6$ & $36.4 \pm 1.8$ & $35.5 \pm 4.7$ & $37.3 \pm 3.9$ & 0.685 \\
\hline $\mathrm{Hb}(\mathrm{g} / \mathrm{dL})$ & $7.21 \pm 0.6$ & $7.72 \pm 0.53$ & $7.46 \pm 0.45$ & $7.32 \pm 0.6$ & 0.738 \\
\hline $\operatorname{RBC}\left(10^{6} / \mu \mathrm{L}\right)$ & $1.64 \pm 0.15$ & $1.81 \pm 0.21$ & $1.77 \pm 0.15$ & $1.70 \pm 0.32$ & 0.795 \\
\hline MCV (fL) & $213.0 \pm 21.2$ & $204.1 \pm 17.3$ & $205.9 \pm 19.0$ & $243.1 \pm 26.4$ & 0.169 \\
\hline $\mathrm{MCH}(\rho g /$ cell $)$ & $45.4 \pm 7.3$ & $43.7 \pm 8.5$ & $43.3 \pm 6.2$ & $48.5 \pm 4.3$ & 0.783 \\
\hline $\mathrm{MCHC}(\mathrm{g} / \mathrm{dL})$ & $21.3 \pm 1.4$ & $21.2 \pm 2.3$ & $21.4 \pm 3.7$ & $19.7 \pm 1.4$ & 0.811 \\
\hline TPP (g/dL) & $6.1 \pm 0.3$ & $6.2 \pm 0.4$ & $6.3 \pm 0.4$ & $6.0 \pm 0.3$ & 0.873 \\
\hline Leu $\left(10^{3} / \mu \mathrm{L}\right)$ & $16.3 \pm 3.6$ & $20.1 \pm 2.3$ & $21.4 \pm 1.1$ & $17.5 \pm 2.5$ & 0.138 \\
\hline Thro $\left(10^{3} / \mu \mathrm{L}\right)$ & $30.1 \pm 1.8 b$ & $37.8 \pm 3.9 \mathrm{ab}$ & $44.4 \pm 1.4 a$ & $40.0 \pm 8.4 a b$ & 0.035 \\
\hline $\operatorname{Lym}\left(10^{3} / \mu \mathrm{L}\right)$ & $7.3 \pm 1.6$ & $8.8 \pm 1.7$ & $8.8 \pm 2.3$ & $6.5 \pm 2.3$ & 0.470 \\
\hline Mon $\left(10^{3} / \mu \mathrm{L}\right)$ & $3.4 \pm 0.6$ & $4.4 \pm 0.2$ & $4.9 \pm 1.3$ & $4.0 \pm 0.8$ & 0.247 \\
\hline Neu $\left(10^{3} / \mu \mathrm{L}\right)$ & $3.4 \pm 0.6 \mathrm{~b}$ & $5.6 \pm 0.9 a b$ & $6.3 \pm 1.6 a$ & $5.8 \pm 0.8 \mathrm{ab}$ & 0.050 \\
\hline Eos $\left(10^{3} / \mu \mathrm{L}\right)$ & $0.35 \pm 0.1$ & $0.46 \pm 0.4$ & $0.34 \pm 0.09$ & $0.23 \pm 0.1$ & 0.446 \\
\hline $\operatorname{SGC}\left(10^{3} / \mu \mathrm{L}\right)$ & $0.32 \pm 0.1$ & $0.61 \pm 0.3$ & $0.49 \pm 0.2$ & $0.76 \pm 0.4$ & 0.115 \\
\hline LRB (OD) & $0.273 \pm 0.10$ & $0.270 \pm 0.11$ & $0.323 \pm 0.03$ & $0.246 \pm 0.05$ & 0.721 \\
\hline
\end{tabular}

Different letter in the same row denote difference by Tukey test $(\alpha=0.05)$

Htc: Hematocrit; Hb: Hemoglobin concentration; RBC: Red Blood Count; MCV: Mean Corpuscular Volume; MHC: Mean Corpuscular Hemoglobin; MCHC: Mean corpuscular hemoglobin concentration; TPP: Total Plasmatic Protein; Leu: Leukocyte number; Thro: Thrombocyte number; Lym: Lymphocyte number; Mon: Monocyte number; Neu: Neutrophil number; Eos: Eosinophil number; SGC: Special Granulocytic Cell; LRB: Leukocyte Respiratory Burst 


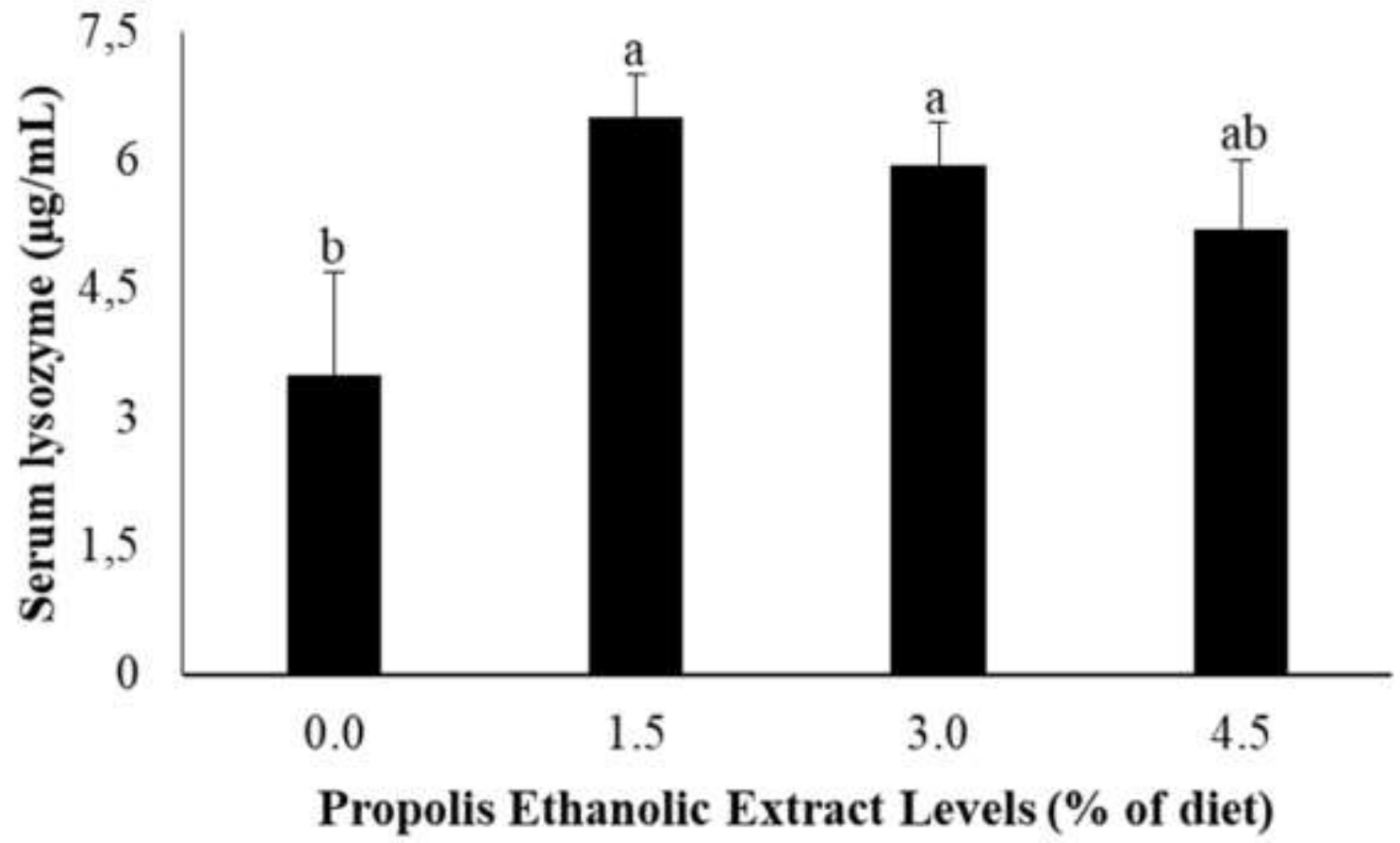

Figure 1. Serum lysozyme concentration of juvenile pacu $P$. mesopotamicus fed increasing levels of dietary brown propolis ethanolic extract. Different letter above each column denote difference by Tukey test $(\alpha=0.05)$.

\section{Growth performance and intestinal morphology}

The effects of dietary PEE on fish growth and intestinal morphology are summarized in Table 3 . There was no significant effect of dietary PEE on fish growth. On the other hand, intestinal morphology was affected $(p<0.05)$ by supplementation of PEE. Intestine muscle layer thickness decreased significantly in fish fed dietary PEE supplementation when compared to control treatment and intestinal villi height also decreased $(p<0.05)$, but only in fish fed $3.0 \%$ dietary PEE.

Table 3. Growth performance and intestine morphology (mean \pm SD) of juvenile pacu Piaractus mesopotamicus fed increasing levels of propolis ethanolic extract in diet for 60 days.

Propolis ethanolic extract levels (\% of diet)

One-way

ANOVA

$\begin{array}{lllll}0.0 & 1.5 & 3.0 & 4.5 & \text { ( } p \text {-values) }\end{array}$

\begin{tabular}{llllll} 
& \multicolumn{1}{c}{$\mathbf{0}$} & $\mathbf{1 . 5}$ & \multicolumn{1}{c}{$\mathbf{3 . 0}$} & \multicolumn{1}{c}{$\mathbf{4 . 5}$} & ( $\boldsymbol{p}$-values) \\
\hline Growth performance & & & & & \\
IW (g/fish) & $28.5 \pm 0.3$ & $28.2 \pm 0.1$ & $28.1 \pm 0.08$ & $28.7 \pm 0.6$ & 0.245 \\
FW (g/fish) & $117.6 \pm 8.7$ & $134.8 \pm 10.9$ & $126.0 \pm 12.9$ & $139.5 \pm 29.5$ & 0.478 \\
WG (g/fish) & $89.1 \pm 8.4$ & $106.0 \pm 11.1$ & $97.9 \pm 12.9$ & $110.8 \pm 29.6$ & 0.482 \\
FC (g/fish) & $2.62 \pm 0.37$ & $3.10 \pm 0.16$ & $3.00 \pm 0.31$ & $2.94 \pm 0.35$ & 0.336 \\
FCR & $1.00 \pm 0.10$ & $1.13 \pm 0.04$ & $1.10 \pm 0.10$ & $1.08 \pm 0.08$ & 0.357 \\
SGR (\%weigh/day) & $2.3 \pm 0.1$ & $2.6 \pm 0.1$ & $2.4 \pm 0.1$ & $2.6 \pm 0.3$ & 0.474 \\
Intestinal morphology & & & & \\
Musc. thickness $(\mu \mathrm{m})$ & $95.0 \pm 21.7 \mathrm{a}$ & $63.1 \pm 10.8 \mathrm{bc}$ & $54.9 \pm 7.3 \mathrm{c}$ & $71.9 \pm 14.5 \mathrm{~b}$ & $<0.001$ \\
Villi height $(\mu \mathrm{m})$ & $202.7 \pm 51.5 \mathrm{a}$ & $189.9 \pm 65.2 \mathrm{a}$ & $129.7 \pm 58.1 \mathrm{~b}$ & $198.6 \pm 42.0 \mathrm{a}$ & 0.014 \\
\hline
\end{tabular}

Different letter in the same row denote difference by Tukey test $(\alpha=0.05)$.

IW: Initial Weight; FW: Final Weight; WG: Weight Gain; FC: Feed Consumption; FRC: Feed Conversion Ratio; SGR: Specific Growth Rate

\section{DISCUSSION}

To improve fish health and growth and avoid disease outbreaks, farmers can use antibiotics, vaccination and/or immunomodulators. The last one, non-specific immunomodulators represents an important tool in modern aquaculture. Fish welfare and health status after dietary PEE supplementation was accessed by hematological and immunological parameters and results showed that long-term administration (60 days) of PEE in fish diet did not induced adverse effects on fish physiology since there was no effect in erythrogram 
and hematimetric indexes when compared to fish fed control diet, representing a desired characteristic for its safe use for feeding protocols in pacu production system. In accordance to our results, rainbow trout supplemented with increasing levels of dietary Iranian PEE for 60 days also presented no intoxication signs of treatments [34].

Immunomodulatory effects of propolis and its extracts are well known in human and animals, including fish $[4,12,14,16]$. Propolis is rich in bioactive substances such as flavonoids and phenolic compounds that can modulate fish immune system, oxidative stress, and disease resistance. For instance, dietary propolis extracts (aqueous or ethanolic) increased serum lysozyme and immune cells production and activity of tilapia species such as Mozambique tilapia Oreochromis mossambicus [19] and Nile tilapia [15,35] as well as for rainbow trout [22,36,37], common carp [23] and Japanese eel [24]. In addition, propolis also mitigated toxic effects and oxidative stress in fish exposed to exogenous chemical compounds or environmental stress $[20,25,38-40]$.

In fact, dietary PEE modulated pacu immune system regarding serum lysozyme concentration and organic defense cells numbers, such as thrombocytes and neutrophils and this result, reflect a better health condition of fish and capacity to respond an infectious disease. Lysozyme is an important bactericidal enzyme produced by leucocytes, including neutrophils, that hydrolyzes the $\beta-1,4$ linkages between $\mathrm{N}$-acetylmuramic acid and $\mathrm{N}$-acetylglucosamine of gram-positive bacteria [41]. Fish thrombocytes are blood cells involved in hemostasis as platelets in mammals, unlike the last one, is only fragments of cells [42]. Moreover, this cells in fish can be related to immune response, since it participates in morbidity process and disease resistance and, also presents phagocytic activity, production of pro inflammatory factors (IL-1 $\beta$ ) and MHC class II molecules in cell surface that suggests their function as cells presenting antigen to $\mathrm{T}$ lymphocytes and participation on the linkage between innate and adaptive immunity [43-47].

Propolis bioactive compounds modulates the immune system via macrophage activation and cytokines production and microbicidal proteins production by macrophages [12] and could explain our results, since the brown propolis herein used was collected from Southwest Region of Parana, Brazil and presented elevated concentration of bioactive compounds [48].

Despite significant effects on fish health, contradictory results can be observed. Nile tilapia supplemented dietary propolis and Aloe barbadensis extract at $0.5,1.0$ and $2.0 \%$ inclusion levels did not present in vivo effects on nonspecific immune system, but in vitro tests showed increased leucocyte phagocytosis activity [49]. In the same way, propolis showed bactericidal properties against Aeromonas hydrophila in vitro, but not necessarily in vivo [50]. The chemical composition of propolis as well as bioactive compounds concentration can vary extensively $[9,51]$, hence, it also can explain variable results on fish immune system.

The growth promoter effect of propolis in fish generally is justified by better absorption and digestion of the dietary nutrients as consequence of the improvement of intestinal health due to its antimicrobial activity $[18,19,36,52]$ and presence of some vitamins and minerals that improve the action of some digestive cofactors [15]. However, as herein observed, some studies have reported no growth-promoting effect in fish fed diets supplemented with propolis [23,34,51,53,54]. It is usual to justify the non-promotion of growth due to factors such as the variability of the chemical composition and palatability of propolis [50,51], time of experimentation, fish species, environmental factors [23]. In this study, the PEE palatability can be excluded, since it was observed no effects on fish feed consumption between treatments.

The effective concentrations of propolis supplementation for growth promotion are very variable, even when supplied for the same fish species. For example, the growth-promoting effect of PEE for Nile tilapia was recorded in minimum doses ranging from $5 \mathrm{~g} / \mathrm{kg}$ (55) to $10 \mathrm{~g} / \mathrm{kg}$ (15) and for rainbow trout from $2 \mathrm{~g} / \mathrm{kg}$ (36) to $10 \mathrm{~g} / \mathrm{kg}$ (52). Moreover, this research is pioneers on the use of propolis in neotropical fish pacu and point the need for further studies on this topic for specie.

Fish digestive system and its integrity at tissue and cellular levels can directly influence nutrient absorption and growth. Its suggested that the antibacterial activity of propolis compounds improves intestinal health and mucous cell numbers [9]. The increase in mucus production by enterocytes also improve the digest viscosity and could stimulate the intestine muscular layer development to move the alimentary bolus trough digestive tract [33]. However, our study did not confirm this hypothesis and significant effect on intestinal villi height and muscular layer thickness herein observed are inconclusive.Fish digestive system shows high phenotypic plasticity in response to diet composition [56] and this, can be considered. In addition, Nile tilapia post larvae and fingerlings fed increasing levels of dietary PEE did not show changes in intestinal villi height [51] and reinforces that, the mode of action of propolis on fish gut morphology are still unclear. 


\section{CONCLUSION}

This study is pioneering in use of dietary PEE for neotropical fish pacu. In fact, bioactive compounds at $3.0 \%$ PEE supplementation modulated pacu immune system and corroborate the use of this natural compound as health promoter and does not present toxic effect for fish. However, sequential studies on time, dose and administration route and reliable chemical standardization of different propolis samples as well as research on pacu physiology and immunology are scarce and still necessary for its safe use in aquaculture.

Funding: This research was funded by Conselho Nacional de Desenvolvimento Científico e Tecnológico (CNPq proc. 477522/2012-2) and Coordenação de Aperfeiçoamento de Pessoal de Nível Superior (CAPES) for master scholarship granted to A. Muzzolon.

Acknowledgments: Authors are indebted Anhambi Alimentos (Itapejara d'Oeste, PR, Brazil) for providing the practical diet formulation mixture.

Conflict of Interest Statement: The authors declare that they have no conflict of interest.

\section{REFERENCES}

1. FAO. The State of World Fisheries and Aquaculture 2020 [Internet]. FAO; 2020. 200 p. Available from: http://www.fao.org/documents/card/en/c/ca9229en

2. Saint-paul U. Native fish species boosting Brazilian's aquaculture development Espécies nativas de peixes impulsionam o desenvolvimento da aquicultura brasileira. Acta Fish Aquat Res. 2017;5(1):1-9.

3. Mehana E, Rahmani A, Aly S. Immunostimulants and Fish Culture: An Overview. Annu Res Rev Biol [Internet]. 2015 Jan 10;5(6):477-89. Available from: http://www.sciencedomain.org/abstract.php?iid=795\&id=32\&aid=6817

4. Wang W, Sun J, Liu C, Xue Z. Application of immunostimulants in aquaculture: current knowledge and future perspectives. Aquac Res [Internet]. 2017 Jan;48(1):1-23. Available from: http://doi.wiley.com/10.1111/are.13161

5. Meena DK, Das P, Kumar S, Mandal SC, Prusty AK, Singh SK, et al. Beta-glucan: An ideal immunostimulant in aquaculture (a review). Fish Physiol Biochem. 2013;39(3):431-57.

6. Belém-Costa A, Cyrino JEP. Antibiotic resistence of Aeromonas hydrophila isolated from Piaractus mesopotamicus (Holmberg, 1887) and Oreochromis niloticus (Linnaeus, 1758). Sci Agric. 2006 Jun;63(3):281-4.

7. Leal MC, Calado R. The key role of functional aquafeeds to achieve a more sustainable aquaculture. J World Aquac Soc. 2019;50(6):1044-7.

8. Boyd CE, McNevin AA, Clay J, Johnson HM. Certification issues for some common aquaculture species. Rev Fish Sci. 2005;13(4):231-79.

9. de la Cruz-Cervantes JA, Benavides-González F, Sánchez-Martínez JG, Vázquez-Sauceda M de la L, Ruiz-Uribe AJ. Propolis in Aquaculture: A Review of Its Potential. Rev Fish Sci Aquac [Internet]. 2018;26(3):337-49. Available from: https://doi.org/10.1080/23308249.2018.1424798

10. Oldoni TLC, Oliveira SC, Andolfatto S, Karling M, Calegari MA, Sado RY, et al. Chemical Characterization and Optimization of the Extraction Process of Bioactive Compounds from Propolis Produced by Selected Bees Apis mellifera. J Braz Chem Soc. 2015;26(10):2054-62.

11. Bankova V. Recent trends and important developments in propolis research. Evidence-based Complement Altern Med. 2005;2(1):29-32.

12. Sforcin JM. Propolis and the immune system: a review. J Ethnopharmacol. 2007;113(1):1-14.

13. Quintino RL, Reis AC, Fernandes CC, Martins CHG, Colli AC, Crotti AEM, et al. Brazilian Green Propolis: Chemical Composition of Essential Oil and Their In Vitro Antioxidant, Antibacterial and Antiproliferative Activities. Brazilian Arch Biol Technol. 2020;63:1-9.

14. Oršolić N, Bašić I. Immunomodulation by water-soluble derivative of propolis: A factor of antitumor reactivity. J Ethnopharmacol. 2003;84(2-3):265-73.

15. Abd-El-Rhman AMM. Antagonism of Aeromonas hydrophila by propolis and its effect on the performance of Nile tilapia, Oreochromis niloticus. Fish Shellfish Immunol [Internet]. 2009;27(3):454-9. Available from: http://dx.doi.org/10.1016/j.fsi.2009.06.015

16. Sforcin JM, Bankova V. Propolis: Is there a potential for the development of new drugs? J Ethnopharmacol. 2011;133(2):253-60.

17. Silva JC, Rodrigues S, Feás X, Estevinho LM. Antimicrobial activity, phenolic profile and role in the inflammation of propolis. Food Chem Toxicol. 2012;50(5):1790-5. 
18. Meurer F, Matiuzzi da Costa M, de Barros DAD, Leal de Oliveira ST, da Paixão PS. Brown propolis extract in feed as a growth promoter of Nile tilapia (Oreochromis niloticus, Linnaeus 1758) fingerlings. Aquac Res. 2009 Mar;40(5):603-8.

19. Acar Ü. Effects of diet supplemented with ethanolic extract of propolis on growth performance, hematological and serum biochemical parameters and disease resistance of Mozambique tilapia (Oreochromis mossambicus) against Streptococcus iniae. Aquaculture [Internet]. 2018;495(January):339-44. Available from: https://doi.org/10.1016/j.aquaculture.2018.06.007

20. Enis Yonar M, Mişe Yonar S, Silici S. Protective effect of propolis against oxidative stress and immunosuppression induced by oxytetracycline in rainbow trout (Oncorhynchus mykiss, W.). Fish Shellfish Immunol. 2011;31(2):31825.

21. Aldemir OS, Selamoglu Z, Gulhan MF, Cakir O, Ozdemir I, Dastan SD, et al. Role of propolis on oxidative stress in various tissues of fish. Fresenius Environ Bull. 2014;23(12C):3546-50.

22. Choobkar N. Persian bee propolis and pollen extracts enhanced the non-specific immune response of rainbow trout (Onchorhynchus mykiss) and resistance against Aeromonas hydrophila. Iran J Fish Sci. 2017;16(2):654-67.

23. Alishahi M, Tulaby Dezfuly Z, Mesbah M. Effects of alcoholic and aqueous extract of propolis on growth performance, hemato-immunological parameters and disease resistance of common carp (Cyprinus carpio). Turkish J Fish Aquat Sci. 2018;18(11):1245-54.

24. Bae JY, Park GH, Lee JY, Okorie OE, Bai SC. Effects of dietary propolis supplementation on growth performance, immune responses, disease resistance and body composition of juvenile eel, Anguilla japonica. Aquac Int. 2012;20(3):513-23.

25. Hassaan MS, EL Nagar AG, Salim HS, Fitzsimmons K, El-Haroun ER. Nutritional mitigation of winter thermal stress in Nile tilapia by propolis-extract: Associated indicators of nutritional status, physiological responses and transcriptional response of delta-9-desaturase gene. Aquaculture. 2019 Sep;511(March):734256.

26. Valladão GMR, Gallani SU, Pilarski F. South American fish for continental aquaculture. Rev Aquac [Internet]. 2018 Jun;10(2):351-69. Available from: http://doi.wiley.com/10.1111/raq.12164

27. Wintrobe MM. Variations on the size and hemoglobin content of erythrocytes in the blood of various vertebrates. Folia Haematol. 1934;51:32-49.

28. Rosenfeld G. Corante pancromico para hematologia e citologia clinica. Nova combinação dos componentes do May-Grünwald e do Giemsa num só corante de emprego rapido. Mem Inst Butantan. 1947;20:329-34.

29. Ishikawa ANM, Ranzani-Paiva MJT, Lombardi J V. Metodologia para quantificação de leucócitos totais em peixe, OREOCHROMIS NILOTICUS. Arch Vet Sci [Internet]. 2008 Jul 15;13(1):54-63. Available from: http://revistas.ufpr.br/veterinary/article/view/11560

30. Sado RY, Bicudo ÁJDA, Cyrino JEP. Feeding Dietary Mannan Oligosaccharides to Juvenile Nile Tilapia, Oreochromis niloticus, Has No Effect on Hematological Parameters and Showed Decreased Feed Consumption. J World Aquac Soc [Internet]. 2008 Dec;39(6):821-6. Available from: http://doi.wiley.com/10.1111/j.17497345.2008.00219.x

31. Biller-Takahashi J, Takahashi L, Saita M, Gimbo R, Urbinati E. Leukocytes respiratory burst activity as indicator of innate immunity of pacu Piaractus mesopotamicus. Brazilian J Biol [Internet]. 2013 May;73(2):425-9. Available from: http://www.scielo.br/scielo.php?script=sci_arttext\&pid=S1519-69842013000200425\&lng=en\&tlng=en

32. Abreu J, Marzocchi-Machado C, Urbaczek A, Fonseca L, Urbinati E. Leukocytes respiratory burst and lysozyme level in pacu (Piaractus mesopotamicus Holmberg, 1887). Brazilian J Biol [Internet]. 2009 Nov;69(4):1133-9. Available from: http://www.scielo.br/scielo.php?script=sci_arttext\&pid=S151969842009000500018\&lng=en\&tIng=en

33. Sado RY, Raulino-Domanski F, de Freitas PF, Sales FB. Crecimiento, estado inmunológico y morfología intestinal de la tilapia del Nilo alimentadas con prebióticos (Mananoligosacáridos-MOS) en la dieta. Lat Am J Aquat Res. 2015;43(5):944-52.

34. Beyraghdar Kashkooli O, Ebrahimi Dorcheh E, Mahboobi-Soofiani N, Samie A. Long-term effects of propolis on serum biochemical parameters of rainbow trout (Oncorhynchus mykiss). Ecotoxicol Environ Saf [Internet]. 2011;74(3):315-8. Available from: http://dx.doi.org/10.1016/j.ecoenv.2010.10.014

35. Dotta G, Brum A, Jeronimo GT, Maraschin M, Martins ML. Effect of dietary supplementation with propolis and Aloe barbadensis extracts on hematological parameters and parasitism in Nile tilapia. Rev Bras Parasitol Veterinária. 2015;24(1):66-71. 
36. Deng J, An Q, Bi B, Wang Q, Kong L, Tao L, et al. Effect of ethanolic extract of propolis on growth performance and plasma biochemical parameters of rainbow trout (Oncorhynchus mykiss). Fish Physiol Biochem. 2011 Dec;37(4):959-67.

37. Talas ZS, Gulhan MF. Effects of various propolis concentrations on biochemical and hematological parameters of rainbow trout (Oncorhynchus mykiss). Ecotoxicol Environ Saf [Internet]. 2009;72(7):1994-8. Available from: http://dx.doi.org/10.1016/j.ecoenv.2009.04.011

38. Enis Yonar M, Yonar SM, Ural M şener, Silici S, Düşükcan M. Protective role of propolis in chlorpyrifos-induced changes in the haematological parameters and the oxidative/antioxidative status of Cyprinus carpio carpio. Food Chem Toxicol. 2012;50(8):2703-8.

39. Kelestemur GT, Seven PT, Yilmaz S. Effects of dietary propolis and vitamin E on growth performance and antioxidant status in blood of juvenile Rainbow trout, Oncorhynchus mykiss (Teleostei: Salmoniformes) under different flow rates. Zoologia. 2012;29(2):99-108.

40. Hamed HS, Abdel-Tawwab M. Ameliorative effect of propolis supplementation on alleviating bisphenol-A toxicity: Growth performance, biochemical variables, and oxidative stress biomarkers of Nile tilapia, Oreochromis niloticus (L.) fingerlings. Comp Biochem Physiol Part - C Toxicol Pharmacol [Internet]. 2017;202(August 2017):63-9. Available from: http://dx.doi.org/10.1016/j.cbpc.2017.08.001

41. Saurabh S, Sahoo PK. Lysozyme: an important defence molecule of fish innate immune system. Aquac Res [Internet]. 2008 Feb;39(3):223-39. Available from: http://doi.wiley.com/10.1111/j.1365-2109.2007.01883.x

42. Tavares-Dias M, Oliveira SR. A review of the blood coagulation system of fish. Rev Rev Bras Biociências Brazilian J Biosci [Internet]. 2009;4849(2):205-24. Available from: http://www.ufrgs.br/seerbio/ojs

43. Köllner B, Fischer U, Rombout JHW., Taverne-Thiele J., Hansen J. Potential involvement of rainbow trout thrombocytes in immune functions: a study using a panel of monoclonal antibodies and RT-PCR. Dev Comp Immunol [Internet]. $2004 \quad$ Aug;28(10):1049-62. Available from: https://linkinghub.elsevier.com/retrieve/pii/S0145305X04000588

44. Fink IR, Ribeiro CMS, Forlenza M, Taverne-Thiele A, Rombout JHWM, Savelkoul HFJ, et al. Immune-relevant thrombocytes of common carp undergo parasite-induced nitric oxide-mediated apoptosis. Dev Comp Immunol [Internet]. 2015;50(2):146-54. Available from: http://dx.doi.org/10.1016/j.dci.2015.02.008

45. Ferdous F, Scott TR. A comparative examination of thrombocyte/platelet immunity. Immunol Lett [Internet]. 2015 Jan;163(1):32-9. Available from: http://dx.doi.org/10.1016/j.imlet.2014.11.010

46. Passantino L, Cianciotta A, Patruno R, Ribaud MR, Jirillo E, Passantino GF. Do Fish Thrombocytes Play an Immunological Role? Their Cytoenzymatic Profiles and Function During an Accidental Piscine Candidiasis in Aquarium. Immunopharmacol Immunotoxicol [Internet]. 2005 Jan 8;27(2):345-56. Available from: http://www.tandfonline.com/doi/full/10.1081/IPH-200067959

47. Stosik M, Tokarz-Deptuła B, Deptuła W. Characterisation of thrombocytes in Osteichthyes. J Vet Res [Internet]. 2019 Mar 1;63(1):123-31. Available from: https://content.sciendo.com/doi/10.2478/jvetres-2019-0017

48. Calegari MA, Prasniewski A, da Silva C, Sado RY, Maia FMC, Tonial LMS, et al. Propolis from Southwest of Parana produced by selected bees: Influence of seasonality and food supplementation on antioxidant activity and phenolic profile. An Acad Bras Cienc. 2017 Feb;89(1):45-55.

49. Dotta G, de Andrade JIA, Tavares Gonçalves EL, Brum A, Mattos JJ, Maraschin M, et al. Leukocyte phagocytosis and lysozyme activity in Nile tilapia fed supplemented diet with natural extracts of propolis and Aloe barbadensis. Fish Shellfish Immunol. 2014;39(2):280-4.

50. Orsi RO, dos Santos VG, Pezzato LE, de Carvalho PLPF, Teixeira CP, Freitas JMA, et al. Activity of Brazilian propolis against Aeromonas hydrophila and its effect on Nile tilapia growth, hematological and non-specific immune response under bacterial infection. An Acad Bras Cienc. 2017;89(3):1785-99.

51. Dos Santos LD, Zadinelo I V., Silva LCR DA, Zilli RL, Barreiros MAB, Mauerwerk MT, et al. Alcoholic extract of propolis in Nile tilapia post-larvae and fingerlings' diets: effects on production performance, body composition and intestinal histology. An Acad Bras Cienc. 2019;91(2).

52. Tuna Keleştemur G, Seven I. Effects of dietary propolis and vitamin E on growth performance and antioxidant status in juvenile rainbow trout ( Oncorhynchus mykiss ) under different flow rate. Aquac Res. 2013 Jun;44(7):1120_ 31.

53. Cuesta A, Rodríguez A, Esteban MÁ, Meseguer J. In vivo effects of propolis, a honeybee product, on gilthead seabream innate immune responses. Fish Shellfish Immunol. 2005 Jan;18(1):71-80. 
54. Uczay J, Pianesso D, Adorian TJ, Mombach PI, Coldebella IJ, Lazzari R. Própolis em dietas para o jundiá (teleostei, pimelodidae). Biosci J. 2014;30(6):1912-8.

55. Wafaa E, Doaa I, El-Murr A, Rania M. Effects of dietary inclusion of black cumin seeds, green tea and propolis extraction on growth parameters, body composition and economic efficiency of Nile tilapia, Oreochromis niloticus. World J Fish Mar Sci. 2014;6(5):447-52.

56. Rodrigues APO, Pauletti P, Kindlein L, Cyrino JEP, Delgado EF, MacHado-Neto R. Intestinal morphology and histology of the striped catfish Pseudoplatystoma fasciatum (Linnaeus, 1766) fed dry diets. Aquac Nutr. 2009;15(6):559-63.

CC (7) (5) 2021 by the authors. Submitted for possible open access publication under the terms and (c) (1) conditions of the Creative Commons Attribution (CC BY NC) license NC (https://creativecommons.org/licenses/by-nc/4.0/). 